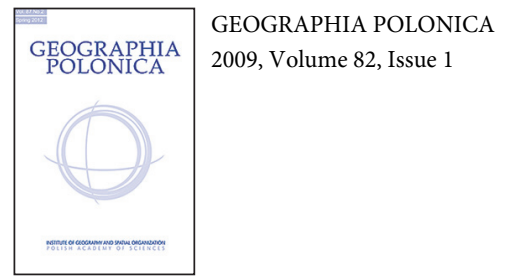

\title{
EXTREME WATER LEVEL FLUCTUATIONS ALONG THE POLISH COAST
}

\author{
BERNARD WIŚNIEWSKI*, TOMASZ WOLSKI**, \\ HALINA KOWALEWSKA-KALKOWSKA**, JERZY CYBERSKI*** \\ *Maritime University of Szczecin, \\ Wały Chrobrego 1, 70-500 Szczecin, Poland \\ ${ }^{* *}$ Institute of Marine Sciences, University of Szczecin, \\ Waska 13, 71-415 Szczecin, Poland \\ *** Institute of Oceanography, University of Gdańsk, \\ Marszałka J. Piłsudskiego 46, 81-378 Gdynia, Poland \\ E-mail: "natal@univ.szczecin.pl
}

\begin{abstract}
The paper examines annual extreme sea levels along the Polish Baltic coast. The analysis is based on water level data sets collected at gauging stations in Świnoujście, Kołobrzeg, Ustka, and Gdańsk in the years 1946-2001. The article also draws upon historical data. The results of the study show that differences between the maximum and minimum levels have increased, particularly during the last 50 years. Sea level amplitudes tend to be wider in the western part of the Baltic coast than in the eastern part. Extreme sea levels occur in the autumn and winter months.
\end{abstract}

Key words: southern Baltic, extreme sea levels, storm surges, storm falls

\section{INTRODUCTION}

Analysis of extreme sea levels requires the identification and comparison of the highest and lowest levels recorded in a multi-annual period, in a year, a month, or during a storm event. Obviously, the most important data pertain to sea level fluctuations throughout a multi-annual period. This work addresses sea level fluctuations in the period 1946-2001, as recorded at the following four stations on the Polish coast: Świnoujście, Kołobrzeg, Ustka, and Gdańsk. In addition, historical data on the annual maximum and minimum sea levels in Świnoujście (1901-2001) and Gdańsk (1889-2001) is also drawn upon. Moreover, the analysis utilises the absolute maximum and minimum levels at 9 selected stations from when sea level gauging began, as well as of data taken from the relevant literature.

Analysis of the frequency of extreme events can provide the necessary data for the establish- ment of warning systems and varying levels of alarm that can be used by services responsible for, say, flood control, coastal protection, and navigation safety. Fig.1 shows the current major gauging stations recording water levels along the Polish coastline of the Baltic Sea, in the coastal lagoons, and in river mouths. Figs. 2 and 3 illustrate storm-induced damage on the Polish coast.

\section{EXTREME SEA LEVELS IN A MULTI-YEAR PERIOD}

Absolute maximum and minimum sea levels, recorded by gauges and mareographs at the stations since the beginning of recording operations and retrieved from the literature (Cyberski and Wróblewski 1999; Dziadziuszko 1992; Majewski 1986; Majewski and Dziadziuszko 1985; Majewski et al. 1983; Sztobryn and Stigge 2005; Wróblewski 1975, 1982, 1992) 


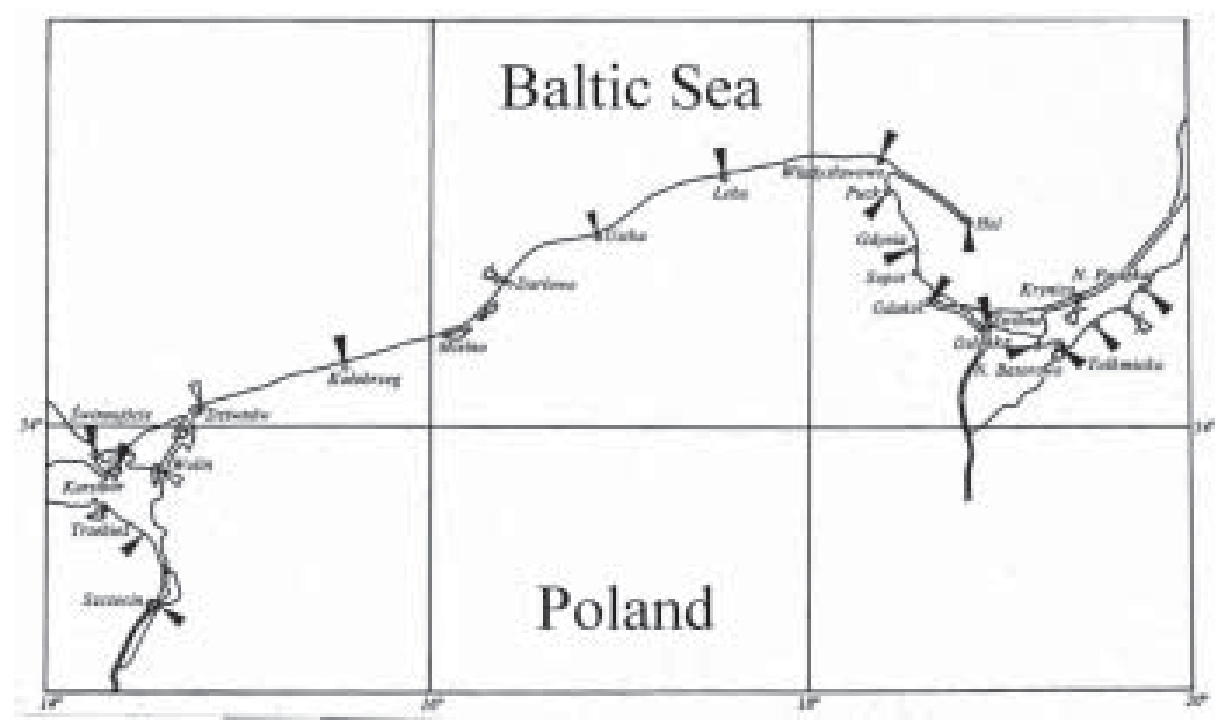

Figure 1. Gauges on the Polish Coast.

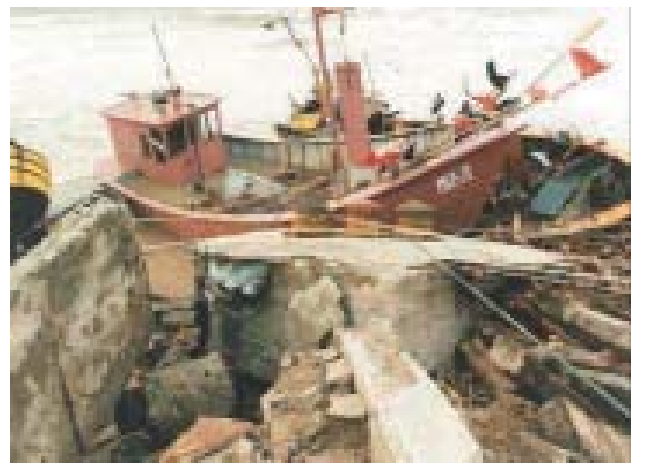

Figure 2. Damage to fishery installations in the vicinity of Międzyzdroje during the storm surge on 3 and 4 November 1995.

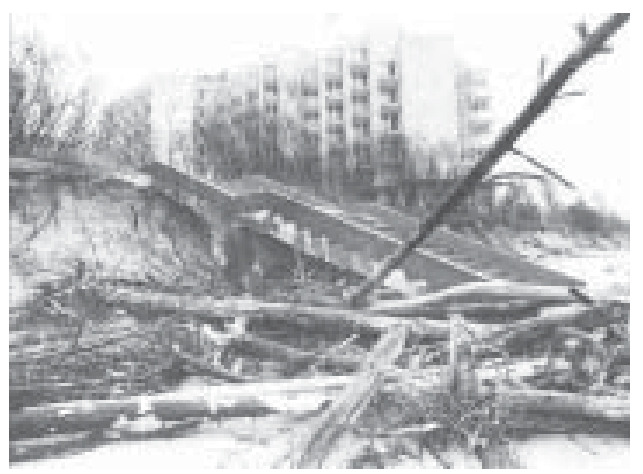

Figure 3. A beach damaged during the storm surge on 3-4 November 1995. are summarised in Table 1. Noteworthy are the wider amplitudes between the extreme levels in the western part of the coast (Świnoujście, Kołobrzeg) compared to those in the eastern part (Gdynia, Hel). Fig. 4 shows the historical maximum and minimum sea levels, their amplitudes being presented in Fig. 5. The graph in Fig. 6, based on a continuous series of data for the period 1946-2001 from 4 major sea ports, supports the pattern indicated above.

Annual maximum and minimum sea levels recorded in Świnoujście in the period 1901-2005 and in Gdańsk in the period 18862001 are shown in Figs. 7 and 8 respectively. The Świnoujście data series shows a tendency towards an increase in the annual maximum sea levels $\left(\mathrm{y}=0.128 \mathrm{x}+588.08 ; \mathrm{R}^{2}\right.$ $=0.0242)$ and towards a small reduction in the minimum levels $(y=-0.0467 x+419.66$; $\left.\mathrm{R}^{2}=0.0083\right)$; i.e., towards an increase in the amplitude. The Gdańsk data indicate an increase in the annual maximum levels (y $\left.=0.2026 \mathrm{x}+574.37 ; \mathrm{R}^{2}=0.0847\right)$ and an increase in the annual minimum levels $(\mathrm{y}=$ $\left.0.1464 \mathrm{x}+432.35 ; \mathrm{R}^{2}=0.1168\right)$.

Another characteristic of multi-annual series of extreme sea levels is their frequency distribution; this makes it possible to determine the distribution of probability of their 
Table 1 Extreme sea levels $[\mathrm{cm}]$ along the Polish coast

\begin{tabular}{lccccc}
\hline \multicolumn{1}{c}{ gauge } & maximum & $\begin{array}{c}\text { Date of } \\
\text { occurrence }\end{array}$ & minimum & $\begin{array}{c}\text { Date of } \\
\text { occurrence }\end{array}$ & amplitude \\
\hline Świnoujście & 696 & 10 Feb. 1874 & 366 & 18 Oct. 1967 & 330 \\
Kołobrzeg & 716 & 9/10 Feb. 1874 & 370 & 4 Nov. 1979 & 346 \\
Darłowo & 659 & 9 Jan. 1914 & 393 & 10 Feb. 1897 & 266 \\
Ustka & 668 & 5 Dec. 1883 & 396 & 10 Feb. 1897 & 272 \\
Leba & 668 & 15 Dec. 1893 & 403 & 31 Dec. 1890 & 265 \\
Władysławowo & 638 & Jan. 1992 & 415 & 25 Feb. 1954, 4 & 223 \\
Hel & 620 & 19 Jan. 1983 & 405 & Jan. 1904 & 215 \\
Gdynia & 626 & 19 Jan. 1983 & 414 & Feb. 1937 & 212 \\
Gdańsk - Nowy Port & 664 & 16 Dec. 1843 & 395 & 20 Jan. 1887 & 269 \\
\hline
\end{tabular}

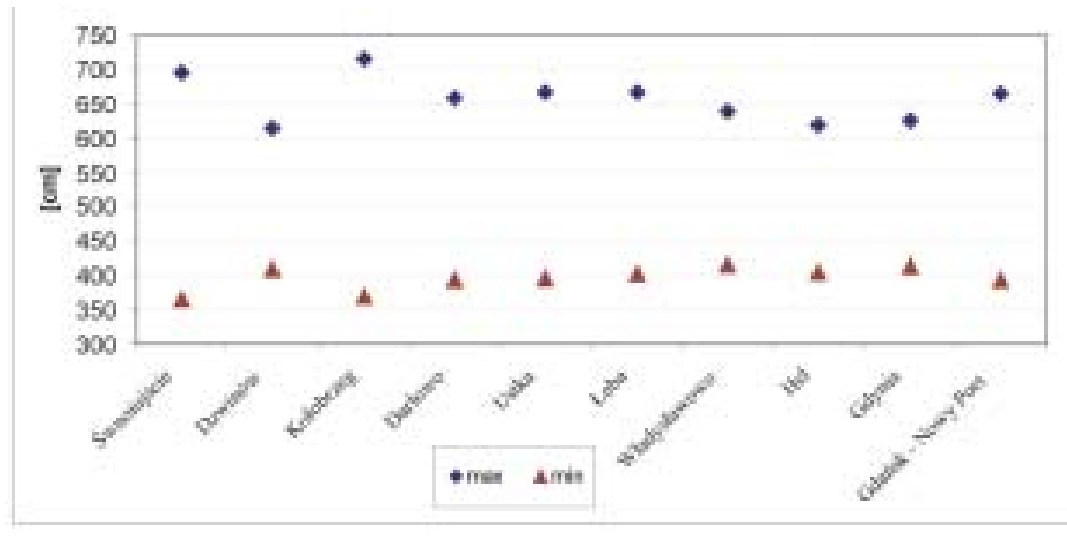

Figure 4. Historical extreme sea levels.

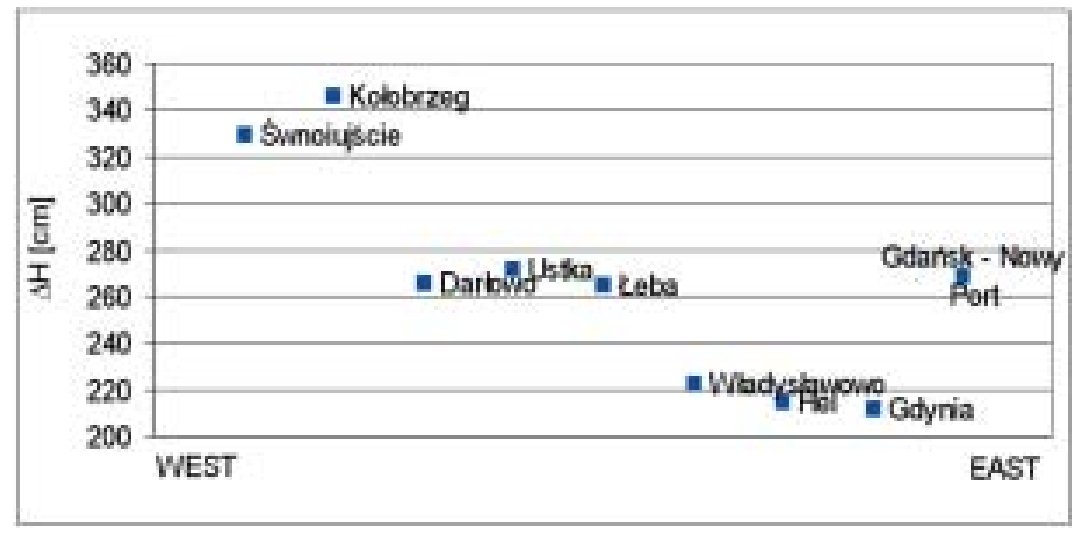

Figure 5. Amplitudes of extreme sea levels along the Polish coast in different periods. 


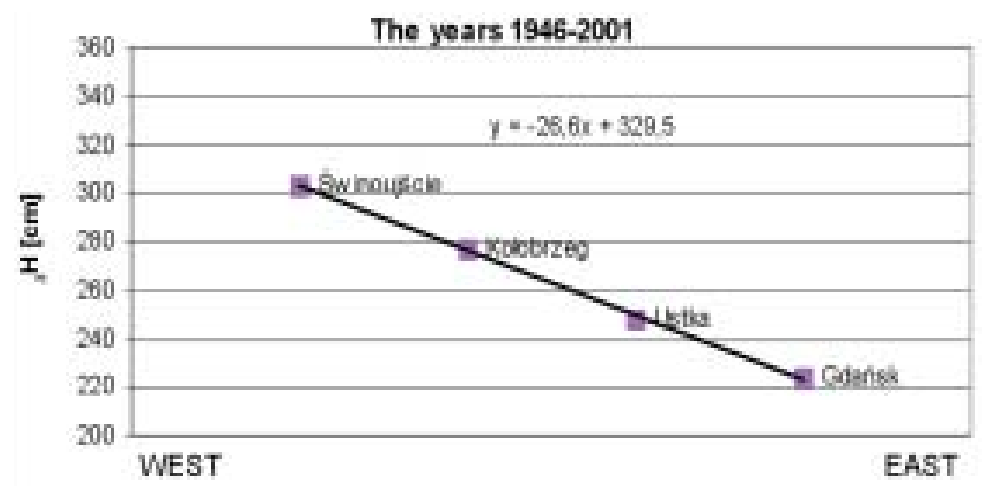

Figure 6. Trends in the change of amplitudes of extreme sea levels along the Polish coast.

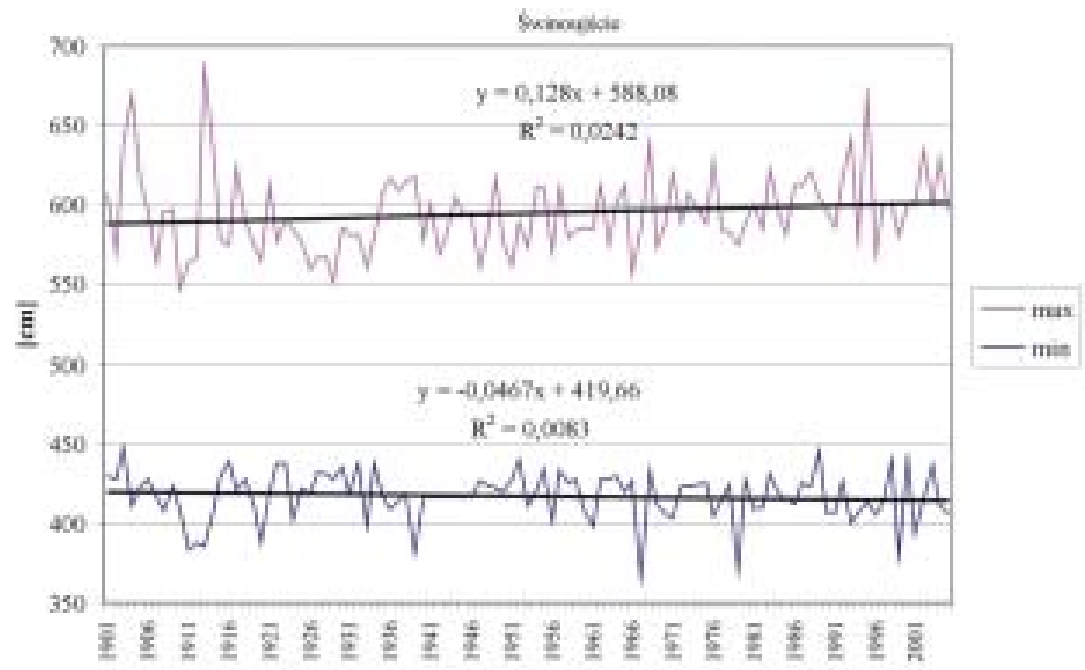

Figure 7. Annual maximum and minimum sea levels in Świnoujście and their trends.

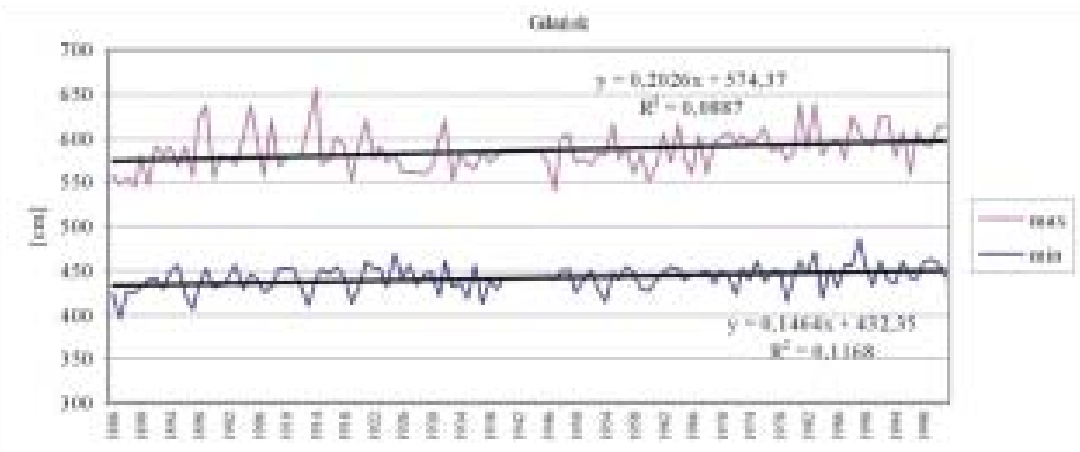

Figure 8. Annual maximum and minimum sea levels in Gdańsk and their trends. 


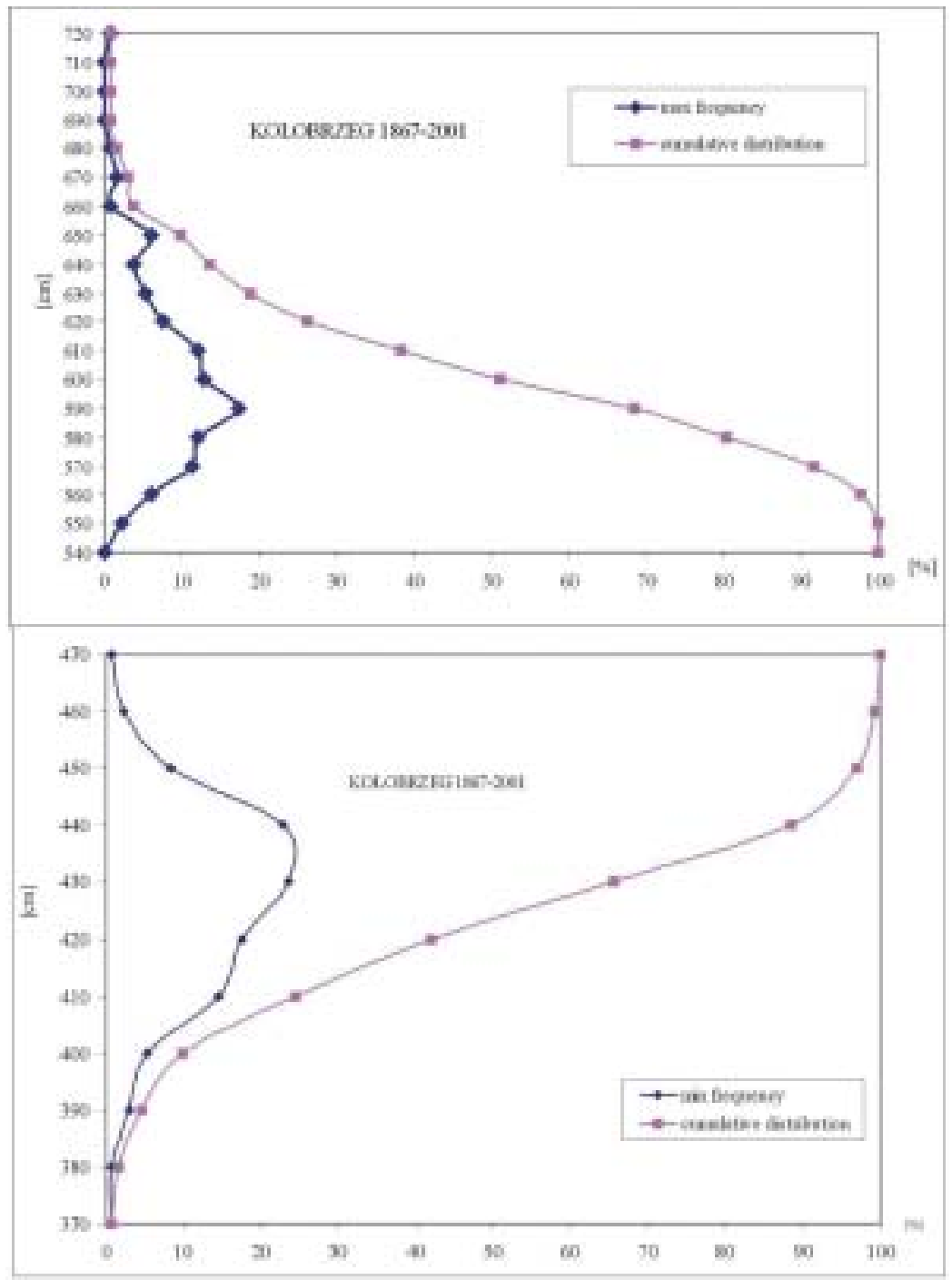

Figure 9. Frequency and the cumulative distribution function of annual maximum and minimum sea levels in Kołobrzeg.

occurrence. The frequency distribution of maximum and minimum sea levels in the period 1867-2001 in Kołobrzeg is shown in Fig. 9. The most frequent among the maximum sea levels was $590 \mathrm{~cm}(90 \mathrm{~cm}$ above the mean level), and $435 \mathrm{~cm}(65 \mathrm{~cm}$ below the minimum level) being the most frequent among the minimum levels. During the period 1867-2001, the maximum level $\geq 650$ $\mathrm{cm}$ occurred with an average frequency of 10 years, the minimum level of $\leq 400 \mathrm{~cm}$ occurred with a similar frequency.

An examination of the temporal distribution of changes in sea levels shows their extremes to occur during autumn-winter, from October through to March (Cyberski and Wróblewski 1999; Dziadziuszko 1992; Dziadziuszko and Jednorał 1996; Majew- 


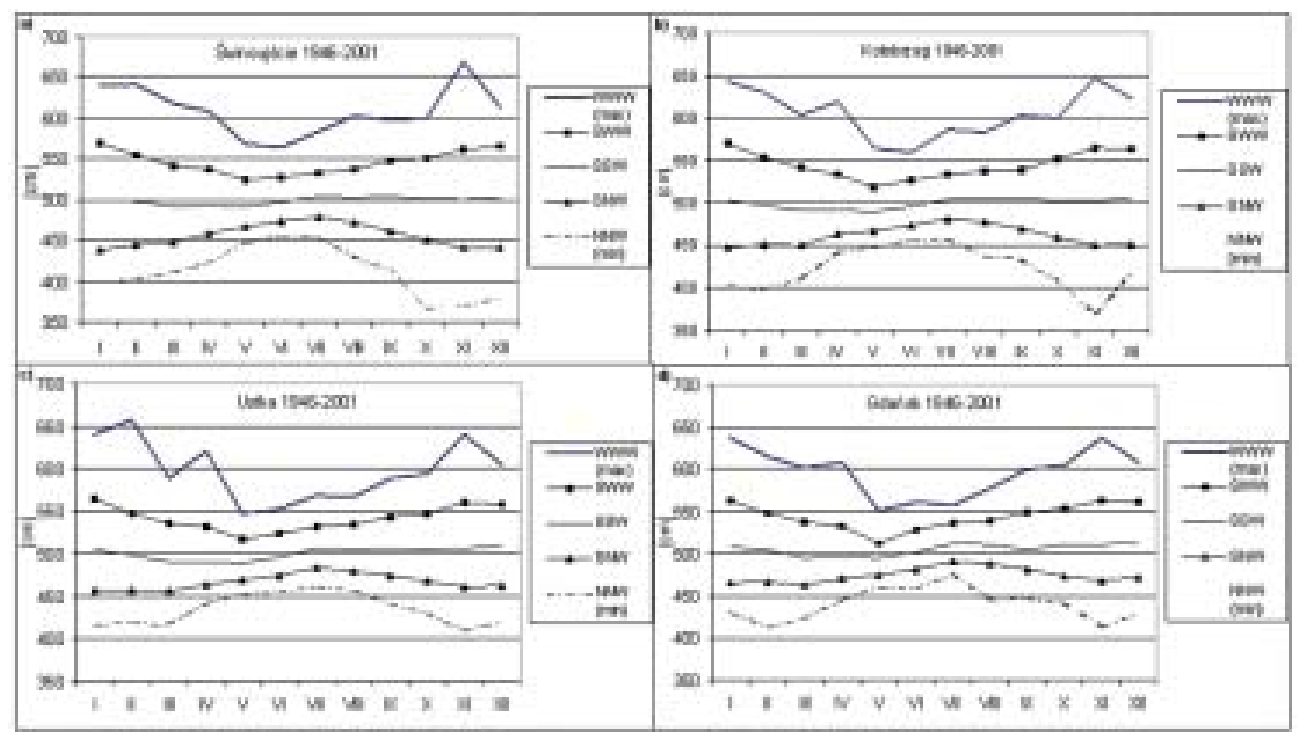

Figure 10. Characteristic seasonal sea levels in a) Świnoujście, b) Kołobrzeg, c) Ustka, d) Gdańsk.

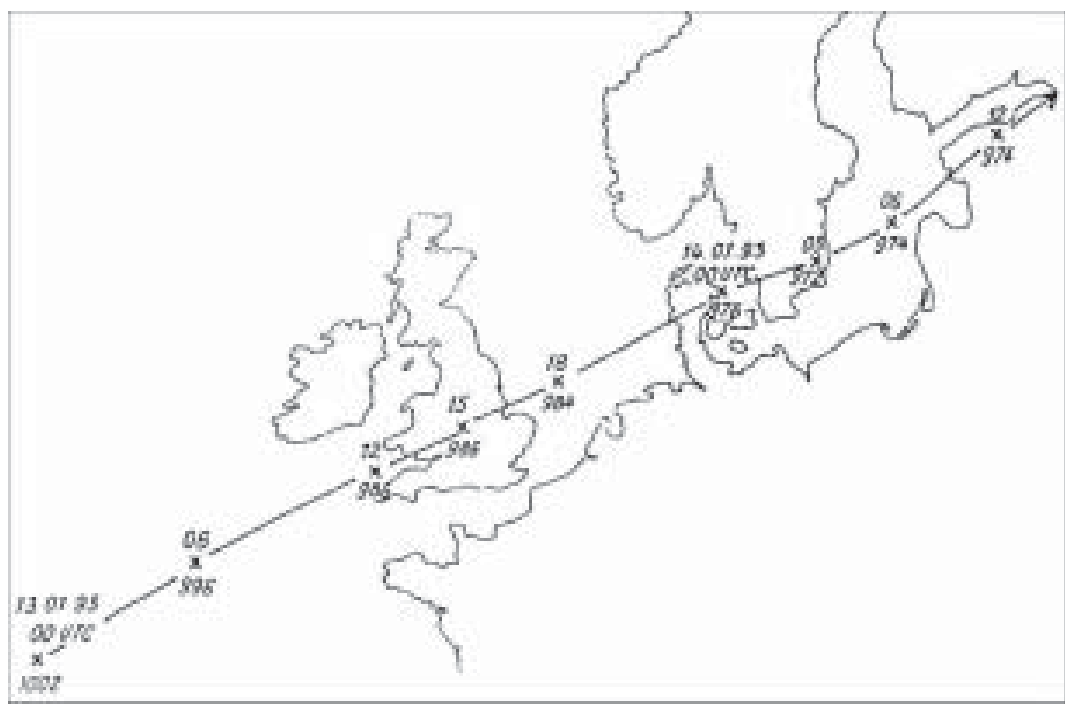

Figure 11. The route of the storm low-pressure system centre for the period 13 January, 00 UTC to 14 January, 12 UTC, 1993.

ski 1986; Majewski and Dziadziuszko 1985; Majewski et al. 1983; Sztobryn and Stigge 2005; Wiśniewski 2003, Wiśniewski et al. 2005; Wróblewski 1975, 1982, 1992). Fig. 10 presents data on characteristic - maximum (WWW) and minimum (NNW) - sea levels in different months of the period 19462001 at four selected stations (Świnoujście, Kołobrzeg, Ustka, Gdańsk). The respective mean values (SWW and SNW) and the monthly mean (SSW) are given as well. 

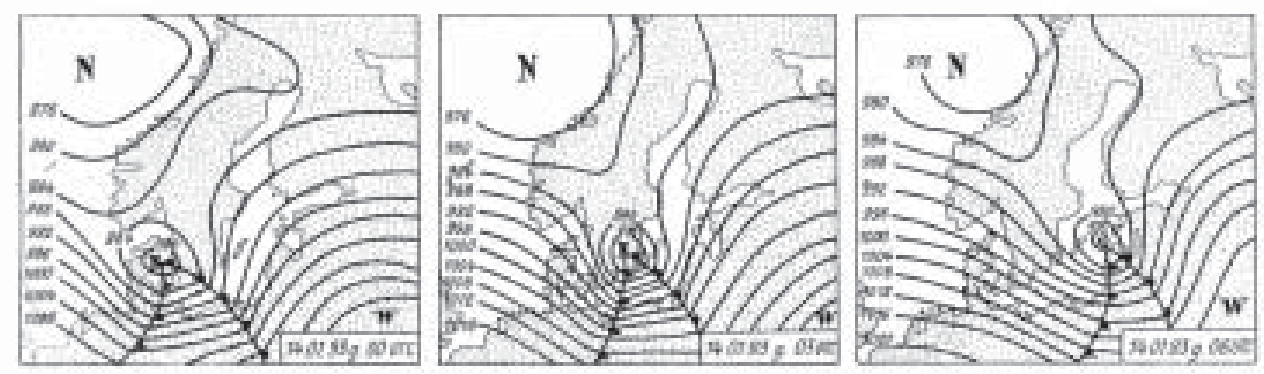

Figure 12. Trajectory of the depression on 13 and 14 January 1993.
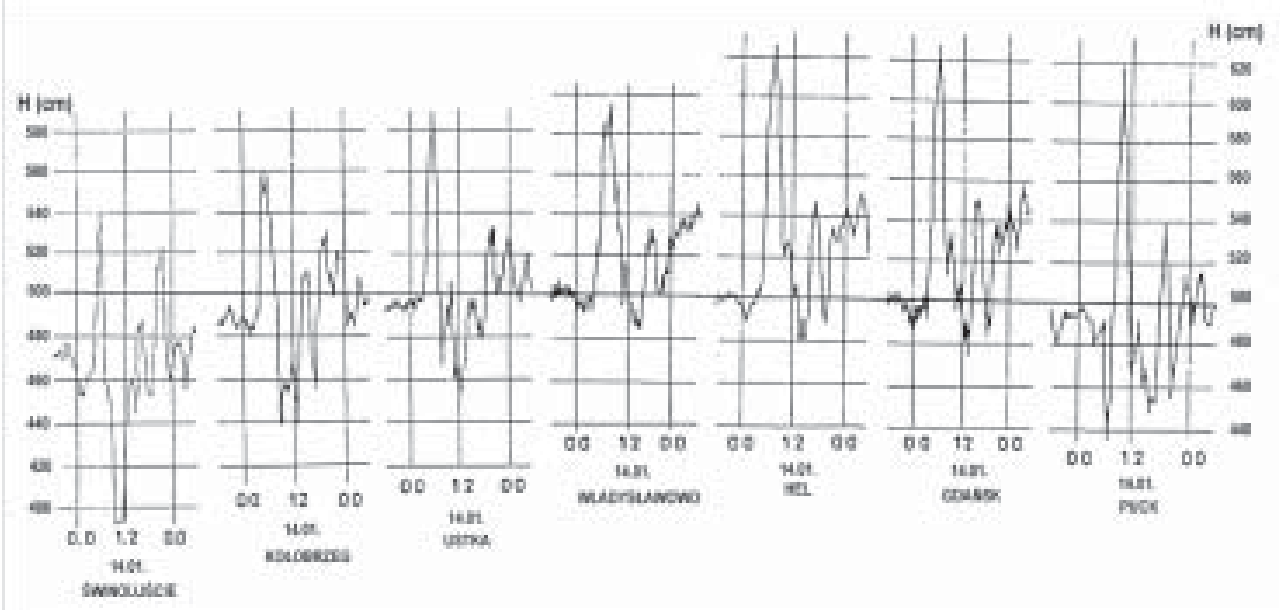

Figure 13. Sea level changes along the Polish coast of the Baltic Sea for the period of 13 January, 18:00 to 15 January, 18:00, 1993.

\section{AN EXAMPLE OF A STORM SURGE EFFECT ON THE SEA LEVEL RISE AND FALL}

An extreme sea level event is related to atmospheric dynamics, particularly to the passage of intense low pressure systems over the Baltic. Such occasions may be marked by high storm surges that can ensue within a few hours. An example of an event of this type is the storm of 13-15 January 1993 documented in the Baltic Sea.

The route of the atmospheric low is depicted in Fig. 11; Fig. 12 shows air pressure distribution, while the associated sea level changes along the Polish coast are illustrated in Fig. 13. An explanation of storm surgerelated changes in sea levels always invokes the actual water volume of the Baltic, wind velocity and direction, duration of the wind field, and sea level deformation by the prevailing pressure system (Wiśniewski 2003; Wiśniewski and Kowalewska-Kalkowska 2001, Wiśniewski et al. 2005). As with the case of tropical cyclones, one may analyse sea level deformation caused by a fast moving concentric low with its positive and negative phase (the so-called baric wave). The selected example of 14 January 1993 shows a movement of the positive phase of the baric wave from the western part of the Polish coast (Świnoujście) to the eastern part (Gdańsk, Puck); the movement followed the trajectory of the concentric atmospheric low. 


\section{CONCLUSIONS}

1. Sea level amplitude (the difference between the maximum and minimum levels) was found to have increased, particularly during the last 50 years.

2. Sea level amplitudes tend to be wider in the western part of the Baltic coast than in the eastern part.

3. Extreme sea levels occur in the autumn and winter months.

4. The factors responsible for the occurrence of extreme sea levels include:

- changes in the air pressure at the sea surface during the passage of a low pressure system; they generate a sea surface deformation, the so-called baric wave, with its positive phase inside the low and its negative phases outside it; those changes vary within $\pm 1.5 \mathrm{~m}$;

- wind forcing, dependent on wind velocity, duration, and direction; sea level fluctuations produced vary within $\pm 0.8 \mathrm{~m}$.

- the present water volume of the Baltic Sea; prolonged stationary weather systems over the Baltic induce volume changes and may cause $\pm 0.5 \mathrm{~m}$ changes in the water level.

5. Although these factors act simultaneously, their effects may be additive, i.e., the net result is an increase or a decrease of the sea level on the coast; or they may be non-additive, e.g., one factor produces a sea level increase, while the action of the other results in a decrease.

6. The rate of sea level fluctuations may vary within $\pm 0.6 \mathrm{~m}$ per hour; however, fluctuations recorded on a per minute basis may be faster, and is accounted for mainly by the baric wave.

\section{ACKNOWLEDGEMENT}

The research in the present paper has been carried out within the framework of the research project entitled "Extreme meteorological and hydrological events in Poland", financed by the Ministry of Science and
Higher Education of Poland (PBZ-KBN-086/ P04/2003). We would like to thank Dr Teresa Radziejewska of the Institute of Marine Science, University of Szczecin, for providing an English translation of the manuscript.

\section{REFERENCES}

Cyberski, J., Wróblewski, A. (1999), Recent and Forecast Changes in Sea Level Along the Polish Coast During the Period 1900 -2100, Quaternary Studies in Poland, Special issue, 77-83.

Dziadziuszko, Z. (1992), Średnie roczne $i$ maksymalne poziomy morza $w$ portach polskich [The mean annual and maximum sea levels in Polish ports], Unpublished typescrpit, Gdynia.

Dziadziuszko, Z., Jednorał, T. (1996), Zagrożenia powodziowe powodowane spiętrzeniami sztormowymi u brzegów Bałtyku i Zalewu Wiślanego [Flooding threat caused by storm surges at the coast of Baltic Sea and Vistula Lagoon], Wiadomości $I M G W, 19$ (15), 3:123-133.

Majewski, A. (1986), Skrajne wahania poziomu wody u polskich wybrzeży Bałtyku [Extreme water level fluctuations along the Baltic coast], Inżynieria Morska, 2:46-50.

Majewski, A., Dziadziuszko, Z. (1985), Niskie stany wody Poludniowego Battyku, Materiaty monograficzne [Low water levels of the southern Baltic, Monograph materials], Instytut Meteorologii i Gospodarki Wodnej (IMGW), Warszawa.

Majewski, A., Dziadziuszko, Z., Wiśniewski, A. (1983), Monografia powodzi sztormowych 1951-1975 [Monograph of storm floods 1951-1975], Wydawnictwa Komunikacji i Łączności, Warszawa.

Sztobryn, M., Stigge, H.J. (eds.) (2005), Wezbrania sztormowe wzdluż potudniowego Battyku (zachodnia i środkowa część) [Storm surges along the southern Baltic Sea (western and central part)], Instytut Meteorologii i Gospodarki Wodnej, Warszawa,

Wiśniewski, B. (2003), The influence of low-pressure systems on water levels in the Odra estuary, in: Trudy analiz, prognozi- 
rovanie $i$ uspravlenie $v$ slozhnyh sistemah, Seviero-Zapadnyj Gosudarstvenyj Zaochnyj Tehnicheskij Universitet, ST. Petersburg, 183-193.

Wiśniewski, B. (2005), Contribution of long-term tide components to sea level variations, Oceanological and Hydrobiological Studies, 34 (2): 5-14.

Wiśniewski, B., Kowalewska-Kalkowska, H. (2001), Wpływ warunków meteorologicznych na wahania poziomu morza i cech fizycznych wód w estuarium Odry [Effects of meteorological conditions on fluctuations of the sea level and of water properties in the Odra estuary], Inżynieria Morska i Geotechnika, 5:236-240.

Wiśniewski, B., Wolski, T., Kowalewska-Kalkowska, H. (2005), Wahania poziomu morza $w$ Świnoujściu i poziomów wód $w$ rejonie ujścia Odry [Sea level fluctuations in Swinoujście and water level variations in the Odra mouth area], in Borówka, R.K. and Musielak, S. (eds.), Srodowisko przyrodnicze wybrzeży Zatoki Pomorskiej i Zalewu Szczecińskiego [Natural environment of the coasts of the Pomeranian Bay and Szczecin Lagoon], Wydawnictwo Oficyna IN PLUS, Szczecin, 113-125.

Wróblewski, A. (1975), Prawdopodobieństwo maksymalnych rocznych poziomów Morza Bałtyckiego w Nowym Porcie, Kołobrzegu i Świnoujściu [The probability of maximum annual Baltic sea levels in Nowy Port, Kołobrzeg and Świnoujście], Oceanology, 6:37-53.
Wróblewski, A. (1982), Prawdopodobieństwo minimalnych rocznych poziomów Morza Bałtyckiego w Nowym Porcie, Kołobrzegu i Świnoujściu [The probability of minimum annual Baltic sea levels in Nowy Port, Kołobrzeg and Świnoujście], Archiwum Hydrotechniki, 29(4):507-516

Wróblewski, A. (1992), Analysis and forecast of long-term sea level changes along the Polish Baltic Sea coast, Part I, Annual sea level maxima, Oceanologia, 33: 65-85.

\section{ADDITIONAL SOURCES OF DATA:}

Rocznik hydrograficzny Morza Bałtyckiego (1946-1960) [Hydrographic year-book for the Baltic Sea (1946-1960)].

Morski Komunikat Hydrologiczno-Meteorologiczny (1961-1990) [Maritime Hydrographic and Meteorological Bulletin (1961-1990)].

Warunki Środowiskowe Polskiej Strefy Południowego Bałtyku (1991-2001) [Environmental conditions in the Polish zone of the southern Baltic Sea (1991-2001)].

Papers first received: February 2007

In final form: February 2009 